\title{
Farming in the Forests of Florida 1
}

\section{Brian Becker and Sarah Workman ${ }^{2}$}

Forest settings can provide an ideal location for cultivating many valued plants which prefer shaded conditions. There are many nontimber forest products including animals and shade tolerant plants which can be intentionally promoted by specific management practices. When considering alternatives for forested land several elements need to be investigated to identify how feasible forest farming will be given the available resources, site characteristics and plans for the land. Ideal forest crops have a relatively high value and are capable of producing profitable volume over the preferred time frame. This fact sheet presents some examples of forest farming appropriate for Florida's forests. This is just a start however; the possibilities of forest farming are limited only by your imagination.

\section{What is Forest Farming?}

Forest farming can be defined as cultivation of plants under a forest canopy (as opposed to wildcrafting, the practice of collecting wild plants and products from a forest). Forest farmers can manage different layers in the forest structure to increase sustainable harvests of forest products from natural forests or plantations. The canopy provides timber, nuts and fruits like pecans and persimmons; the middle layer may be full of mayhaw, vines, palmettos, berries or ornamentals; and the forest floor can be cultivated for medicinal and culinary herbs, roots, mushrooms and landscaping or florist products like flowers and ferns. The multilayered structure of a farmed forest improves wildlife habitat and may increase the aesthetic and recreational value of the property.

\section{Nuts, Fruits, Berries and Gourmet Crops}

Nuts and Fruits: Many tree and shrub species native to Florida and the southeastern United States produce valuable nuts and fruits. For example, naturally-growing pecans (Carya illinoensis), pignut hickory (C. glabra), mockernut hickory $(C$. tomentosa) and black walnuts (Juglans nigra) can be found in our forests. Shade tolerant crops like wildflowers, floral greenery or native fruit trees can also be grown in pecan orchards, providing additional benefits to farmers. The American persimmon (Diospyros virginiana) grows in north and central Florida sandhills, hammocks, bottomlands and old fields. The numerous varieties of oriental persimmons

1. This document, CIR 1434 is one of a series through the Center for Subtropical Agroforestry (CSTAF), School of Forest Resources and Conservation, Institute of Food and Agriculture Sciences, University of Florida. First published March 2003. This publication was produced by the University of Florida with assistance from USDA/CSREES/IFAFS. For more information contact CSTAF, PO Box 110831, Gainesville, FL 32611, (352)846-0146, http://CSTAF.ifas.ufl.edu.

2. Brian Becker, M.S. Candidate, School of Forest Resources and Conservation; Sarah Workman, Visiting Assistant Professor, School of Forest Resources and Conservation and Center for Subtropical Agroforestry, Institute of Food and Agricultural Sciences, University of Florida, Gainesville, 32611.

The Institute of Food and Agricultural Sciences (IFAS) is an Equal Opportunity Institution authorized to provide research, educational information and other services only to individuals and institutions that function with non-discrimination with respect to race, creed, color, religion, age, disability, sex, sexual orientation, marital status, national origin, political opinions or affiliations. U.S. Department of Agriculture, Cooperative Extension Service, University of Florida, IFAS, Florida A. \& M. University Cooperative Extension Program, and Boards of County Commissioners Cooperating. Larry Arrington, Dean 
(D. kaki) are better suited for production and can be grafted onto the rootstock of our naturally occurring persimmon. While the pawpaw (Asimina triloba) will produce well in sunlight, the seedlings require shade for their first couple of years and mature wild pawpaw trees can be found under forest canopies. Likewise, mayhaws (Crataegus aestivalis, C. opaca, and $C$. rufula), which do well on drier soils with more sun, are naturally found on wet, shady sites.

Berries: Blueberries require acidic, organic soils and grow well under pine canopies. Rabbiteye blueberries (Vaccinium ashei) are typically grown in north Florida, and southern highbush (V. corymbosum and $V$. darrowi hybrid) blueberries are grown south of Ocala. A number of other blueberry and huckleberry species also grow well under pine stands, especially with periodic prescribed burning. Florida producers can capitalize on early season prices by putting their blueberries on the market over a month before the rest of the nation, and U-pick operations are popular near urban areas. Deciduous fruit and nut-bearing species typically require a period of winter dormancy to bear. Check on the chilling requirements for the particular cultivar or species to see what is suitable for your area.

Mushrooms: Farmer to chef markets can be developed for herbs, mushrooms and specialty vegetables grown in managed forest settings. Mushroom production under shade can add value to scrap wood and provide additional income for producers. Native edible mushrooms such as chanterelles (Cantharellus spp.) and morels (Morchella spp.) have long been collected. Exotics such as maitake (Grifola frondosa), shiitake (Lentinus edodes) and various oyster mushrooms (Pleurotus spp.) are increasingly cultivated for popular markets. Small forest patches can be cleared for mushrooms like morels that prefer to grow on forest floor litter. Small hardwood logs, less then 15 $\mathrm{cm}$ (6 inches) in diameter, from thinning operations are ideal for the family-business scale production of shiitake and other gourmet mushrooms. In south Florida, innovative producers are growing the medicinal rishi mushroom (Gandoderma lucida) on melaleuca (Melaleuca quinquenervia) logs and oyster and other edible mushrooms on sawmill waste.

Fungal spores, called spawn, required to start production of edible mushrooms are available from seed catalogues and the World Wide Web. Developing markets is a challenge, though producers who are flexible and can meet seasonal production and labor demands have retained steady markets and in some cases, have developed year round enterprises.

\section{Selected Sources for Nuts, Fruits, Berries and Mushrooms:}

Ames, G., 2001. Persimmon Production. Appropriate Technology Transfer for Rural Areas. http://www.attra.org/attra-pub/persimmon.html. Web site accessed August 26, 2002.

Arnold C.E. and T.E. Crocker, 1998. Pecan Production in Florida. Circular 280-D. University of Florida Cooperative Extension Service. http://edis.ifas.ufl.edu/BODY_CV200. Web site accessed August 26, 2002.

Blueberry Information Links, http://www.citygardening.net/blueberryinfo/. Web site accessed on August 25, 2002.

Crocker, T.E. and J.G. Williamson, 2000. Deciduous Fruit for North Florida. Circular 611. University of Florida Cooperative Extension Service. http://edis.ifas.ufl.edu/BODY_MG211. Web site accessed October 3, 2002.

Davies, F.S., 1994. Pruning Blueberries in Florida. Fact Sheet HS 77. University of Florida Cooperative Extension Service. http://edis.ifas.ufl.edu/BODY_MG334. Web site accessed August 26, 2002.

Diver, S. and G. Ames, 2000. Sustainable Pecan Production. Appropriate Technology Transfer for Rural Areas. http://www.attra.org/attra-pub/pecan.html. Web site accessed August 26, 2002.

Hill, D.B.,1999. Farming Exotic Mushrooms in the Forest. Agroforestry Notes \#13. USDA Forest Service, USDA Natural Resources Conservation Service. http://www.unl.edu/nac/afnotes.html. Web site accessed September 18, 2002.

Miller, E.P. and T.E. Crocker, 1994. Oriental Persimmons in Florida. SP 101. University of Florida Cooperative Extension Service. 
http://edis.ifas.ufl.edu/BODY_MG242. Web site accessed August 26, 2002.

Payne, J.A. and G.W. Krewer, 1990. Mayhaw: A new fruit crop for the south. Pp. 317-321. In: J. Janick and J.E. Simon (eds.), Advances in New Crops. Timber Press, Portland, OR.

http://www.hort.purdue.edu/newcrop/ proceedings1990/v1-317.html. Web site accessed August 28, 2002.

Pomper, K., 2002. Pawpaw Information Web Site. Kentucky State Universities Pawpaw Research. http://www.pawpaw.kysu.edu. Web site accessed August 28, 2002.

The Florida Mushroom, http://www.flmushroom.com. Web site accessed August 26, 2002.

The Mushroom Council, http://www.mushroomcouncil.com. Web site accessed August 26, 2002.

Williamson, J. and P. Lyrene, 1997. Florida's Commercial Blueberry Industry. Fact Sheet HS 742. University of Florida Cooperative Extension Service. http://edis.ifas.ufl.edu/BODY_AC031. Web site accessed August 27, 2002.

\section{Medicinal Plants and other Botanicals}

Many shade tolerant medicinal plants grow naturally or were historically cultivated in the forestlands of north-central Florida and the southeast Coastal Plain (See Table). The growing demand for herbal supplements and natural products has led to over-harvesting and decline in natural populations of many species. Cultivation under forest canopies in wild-simulated conditions can produce the supplies needed for these markets as well as maintain the valuable and unique characteristics of the medicinal plants while ensuring the survival of the species.

Saw palmetto: There is a strong demand for saw palmetto (Serenoa repens) berries for the treatment of enlarged prostate condition in men. Berry fruiting is related to the length of time since the last fire. In north-central Florida, saw palmetto requires up to four years to regenerate enough energy to begin producing berries again. By early summer healthy plants can produce as many as 500 berries that can be collected from September to October when they ripen and turn black. The berries should then be cleaned and dried in the sun or in a dryer. Besides our medicinal usage, palmetto berries are an important food source for wildlife such as black bears, white-tailed deer, grey foxes, raccoons, opossums and wild turkey. Additionally, the thickets provide nesting and cover for many species. The endangered Florida panther and the Florida Grasshopper Sparrow prefer palmetto thickets for nesting. The flowers are insect pollinated and are an excellent nectar source for honey bees. With increasing urbanization, saw palmetto has become a popular drought tolerant, though extremely flammable, landscaping plant.

Consider contacting buyers before beginning production of medicinal plants since many plants must be processed fresh. In addition to appropriate harvesting and processing information, buyers may be able to provide valuable propagation and cultivation techniques. People interested in the production of medicinal plants should be aware that the industry is characterized by fluctuating prices which follow supply and demand. The supply and demand of botanicals is in turn, heavily influenced by the publication of scientific research and reports on specific plants and current trends in alternative medicine and natural products.

\section{Selected Sources for Botanicals:}

Christensen, B.V., 1946. Collection and cultivation of medicinal plants of Florida. Micanopy Publishing Co., Micanopy.

Florida Plants Online, http://www.floridaplants.com. Web site accessed November 25, 2002.

Foster, S. and J.A. Duke, 2000. A field guide to medicinal plants and herbs: eastern and central North America. Peterson Field Guide. Houghton-Mifflin Co., Boston.

The Saw Palmetto Harvesting Company, http://www.sawpalmetto.com. Web site accessed August 26, 2002. 
Tanner, G.W., Mullahey, J.J., and D. Maehr, 1996. Saw-palmetto: an ecologically and economically important native palm. Circular WEC-109, University of Florida Cooperative Extension Services. http://edis.ifas.ufl.edu/BODY_UW110. Web site accessed September 18, 2002.

\section{Ornamentals, Cut Flowers \& Other Greenery}

Other examples of forest farming include ferns or other ornamentals grown under shade. Greenery products gathered and produced from forests are sold for floral and holiday markets. Tips clipped from lower limbs of conifer trees serve as raw material for loose greenery, garlands, centerpieces and wreaths or swags. Early in the $20^{\text {th }}$ century, a fern growers association developed in central Florida to supply asparagus fern (Asparagus setaceus) to stores in the northeastern U.S. This cut foliage industry grew as a contract grower-brokerage business and evolved with changing modes of transportation and markets promoting leatherleaf (Rumohra adiantiformis) and asparagus fern. The association continues today with an expanding offering of floral greens and live plants, including ferns grown under shade or planted in native oak forests. Grapevines, willows, crooked wood, variegated and green ivy, spanish moss, palmetto fronds and even kudzu vines have value in these markets. Additionally, Florida and subtropical coastal areas of the southeast U.S. offer many unique native plants such as our palms, blazing stars (Liatris spp.), haws (Viburnum spp.), hollies (Ilex spp.), Florida and star anises (Ilicium spp.), beautybush (Callicarpa americana) and wild poinsettia (Poinsettia cyathophora), which can be grown for ornamental landscaping, cut flowers and seed.

\section{Selected Sources for Ornamentals, Cut Flowers \& Greenery: \\ Evans, M.R., 1993. Producing Blazing Star (Liatris) for Cut Flowers. Circular ENH-111. University of Florida Cooperative Extension Service. http://edis.ifas.ufl.edu/BODY_CN006. Web site accessed November 25, 2002.}

Florida Fern Growers Association Website, http://www.fl-ag.com/ferns. Web site accessed October 10, 2002.

Hamilton, D.F. and J.T. Midcap, 1987. Propagation of Woody Ornamentals by Grafting and Budding. Circular 416. University of Florida Cooperative Extension Service. http://edis.ifas.ufl.edu/EP031. Web site accessed November 27, 2002.

Hamilton, D.F. and J.T. Midcap, 1998. Seed Propagation of Woody Ornamentals. Circular 414. University of Florida Cooperative Extension Service. http://edis.ifas.ufl.edu/EP029. Web site accessed November 27, 2002.

Hamilton, D.F. and J.T. Midcap, 1999. Propagation of Woody Ornamentals by Cuttings. Circular 415. University of Florida Cooperative Extension Service. http://edis.ifas.ufl.edu/EP030. Web site accessed November 27, 2002.

Specialty Cut Flowers Web site, http://hort.ifas.ufl.edu/floriculture/specialty_cut.htm. University of Florida, Commercial Floriculture. Web site accessed November 25, 2002.

\section{Marketing Your Forest Farmed Products}

For some landowners forest farming will be a recreational or retirement hobby, with satisfaction derived from time spent in the forest and materials produced for friends and family. Other landowners will approach forest farming with a distinct financial objective. As with any enterprise, market analysis and a business plan are essential. The first step is to clearly define the objectives of the activity. Preliminary research up front can prevent frustration later. Does the crop have pest or disease problems in certain growing conditions? Will cultivation require irrigation, special labor or other inputs? How can the crop be protected from thieves and hungry animals? How does it fit into the calendar of annual activities already in progress? Managing with an eye for uncertainty and reducing risk can improve cash income for growers. 
Locate potential markets before starting and determine what products they desire. The key to marketing is to produce a product at a competitive price that the market wants; not simply selling what is available. Will you sell in local or regional markets? Are there cooperatives or local buyers involved in marketing the products? A marketing strategy is important for forest farming products and just as important for a farm business as it is for a large company.

A reliable source of technical expertise may be arranged with the assistance of your local county extension professionals. County extension offices can be found on the World Wide Web associated with state universities or in the phonebook under county cooperative extension services. The appropriate production and processing information should be obtained for each product of interest. A schedule of activities required can be developed and the costs and returns determined. By attaching dollar values to these activities and discounting the values of future activities to the present, the net present value (NPV) of the proposed enterprise can be determined. NPV enables alternative proposals that may have vastly different time frames to be compared for determining which one has the greatest economic potential. Finally, develop a management plan for the forest and a business plan for the enterprise. These plans will guide forest farming activities and can assist you as a landowner in obtaining the necessary financing. The cost of developing these activities may also be tax deductible.

\section{Marketing and General Information:}

Chamberlain, J. and A.L. Hammett, 2002. Non-Timber Forest Products: alternatives for landowners. Forest Landowner 61(2): 16-18.

Division of Marketing and Development, Florida Department of Agricultural and Consumer Services, http://www.florida-agriculture.com. Web site accessed August 26, 2002.

Hubbard, W.G., Abt, R.C., Duryea, M.L., and M.G. Jacobson, 1998. Estimating the Profitability of Your Non-Timber Forestland Enterprise. Circular 836, IFAS, University of Florida. http://edis.ifas.ufl.edu/BODY_FR015 or
http://edis.ifas.ufl.edu/pdffiles/FR/FR01500.pdf.

Web sites accessed September 18, 2002.

Josiah, S.J. (ed.), 1998. Proceedings of the North American Conference on Enterprise Development through Agroforestry: Farming the Forest for Specialty Products, October 4-7, 1998, Minneapolis. The Center for Integrated Natural Resources and Agriculture Management, University of Minnesota. http://www.cnr.umn.edu/FR/CINRAM/publications/ proceedings_from_the_1998_specia.htm. Web site accessed September 18, 2002.

Josiah, S.J., 2000. Discovering Profits in Unlikely Places: Agroforestry Opportunities for Added Income. University of Minnesota Extension Service Web site. http://www.extension.umn.edu/distribution/ naturalresources/DD7407.html. Web site accessed September 29, 2002.

Miller-Regaldo, L., 2001. Small Farm Source Book. University of Florida Cooperative Extension Service Website. http://floridasmallfarms.ifas.ufl.edu. Web site accessed September 29, 2002.

UF/IFAS Florida Cooperative Extension Service Website, http://www.ifas.ufl.edu/extension/ces.htm. Website accessed November 27, 2002.

Virginia Tech, Department of Wood Science and Forest Products, Special Forest Products Web site. http://www.sfp.forprod.vt.edu. Web site accessed September 29, 2002.

Vollmers, C. and E. Streed, 1999. Marketing special forest products. University of Minnesota Extension Service Web site. http://www.extension.umn.edu/distribution/ naturalresources/DD7278.html. Web site accessed September 29, 2002. 
Table 1. Selected Medicinal Plants Historically Found in Florida

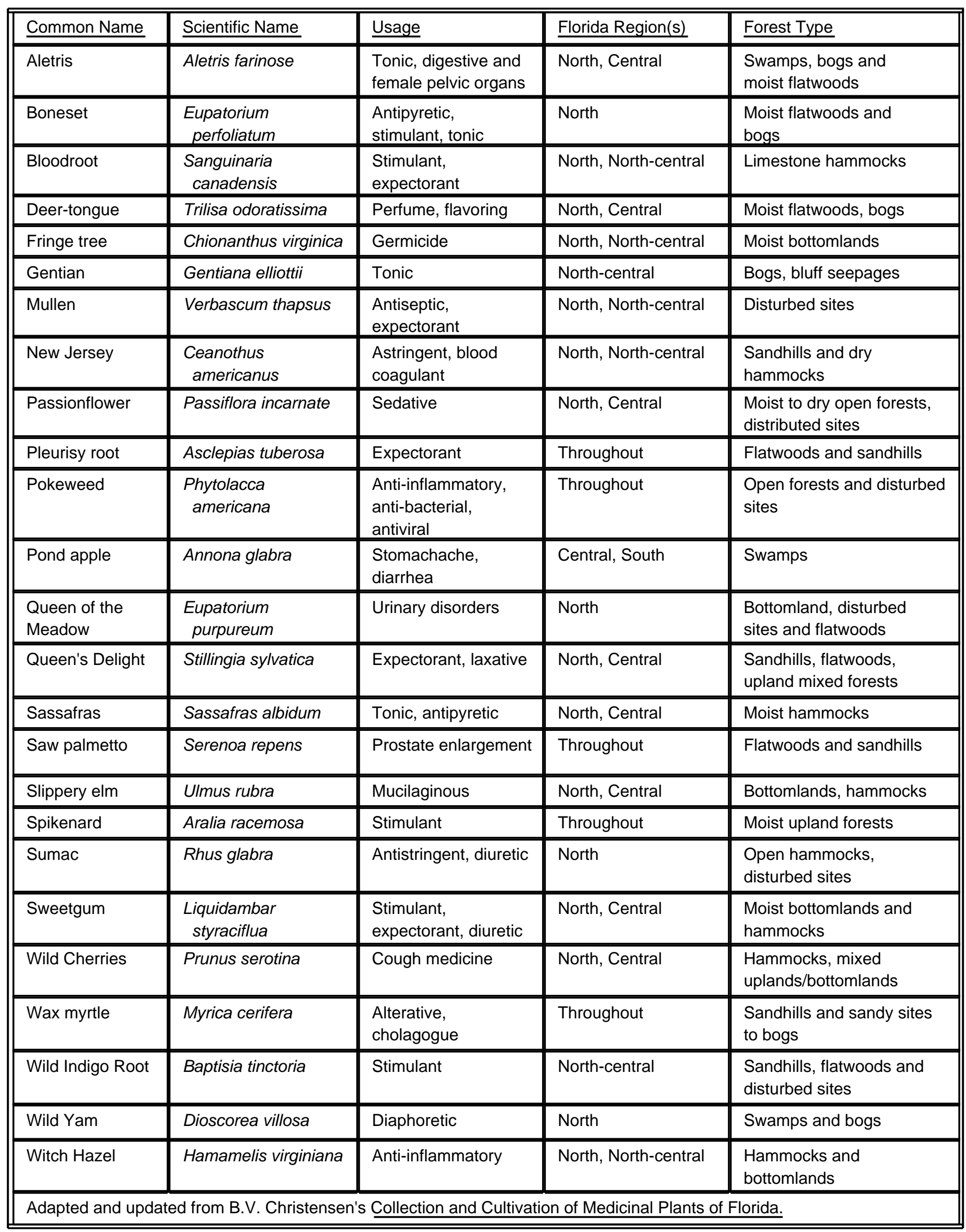

